\title{
A ARTE DE LER: REFLEXÕES SOBRE AS POSSIBILIDADES DE LEITURA SIGNIFICATIVA
}

\author{
$\underline{\text { Maria Julia Souza Silva }}{ }^{1}$; Flávia Aninger de Barros Rocha ${ }^{2}$ \\ Bolsista PROBIC/UEFS, Graduanda em Licenciatura em Letras Vernáculas, Universidade Estadual de Feira de Santana, e-mail: jhulia.s @ hotmail.com \\ Orientadora, Departamento de Letras e Artes, Universidade Estadual de Feira de Santana, e-mail: flavianinger@gmail.com
}

PALAVRAS-CHAVE: abordagem de leitura; reflexão; literatura brasileira.

\section{INTRODUÇÃOO}

Este trabalho se propõe a refletir sobre a construção de experiências diferenciadas na leitura de textos literários, abordando os conhecimentos apresentados pela antropóloga francesa Michèle Petit (1946) reunidos no livro A arte de ler ou como resistir à adversidade (2009) no qual apresenta uma visão particularizada da leitura e da literatura, diferente daquela vivida por nossas escolas e seu público. Acreditando que o modelo utilizado pela escola tradicional está defasado, distante das exigências e interesses do novo público, buscamos outras formas de experiências de leitura significativas para a formação do sujeito leitor.

As reflexões sobre literatura ou leitura recaem, normalmente, no âmbito acadêmico ou de formação profisssional do indivíduo. É indiscutível que o hábito de ler favorece a construção de novos conhecimentos, a aquisição de um vocabulário mais rico e diversificado, além de contribuir para melhorar a escrita. No entanto, como afirmou Marcel Proust (1871-1922), escritor francês, que escreveu Em busca do tempo perdido, a leitura pode ser como uma viagem, um sair de si mesmo, que proporciona ao leitor, após suas reflexões, compreensões novas sobre sua identidade e seu mundo.

A antropóloga francesa Michèle Petit (1946) relata no livro A arte de ler (2009), experiências em que a leitura aparece como um instrumento que vai muito além de ferramenta pedagógica, mas, um suporte, um abrigo para pessoas ou comunidades que vivem adversidades as mais diversas. Em países da América Latina, lidando em bairros com pessoas marcadas pela violência física, psicológica, social, a leitura ou os livros ultrapassam o espaço de informação e conhecimento e fornecem subsídio para a superação da dor, do sofrimento, devolvendo a jovens, crianças e adultos a oportunidade de um resgate de si mesmos e reconstrução de suas vidas.

O reinventar-se proposto pela literatura se torna possível porque a leitura promove a construção de sentidos. Apesar dos conflitos internos ou externos, há um sentido que se constrói naquilo que vive o leitor, ao ler um livro ou ouvir uma história, conto, lenda ou mito. No momento em que pensam sobre o que estão lendo ou ouvindo, segundo a autora, pode acontecer uma espécie de catarse, uma revelação: "Esses momentos em que se levantam os olhos do livro e onde se esboça uma poética discreta, onde surgem associações inesperadas" (PETIT, 2009, p. 24). A leitura promove um momento de encontro ao redor de uma história e a partir daí suscitará discussões de questões pessoais e coletivas, como nos tempos antigos em que os homens se reuniam ao redor da fogueira para ouvir as histórias de seus antepassados, suas próprias histórias, portanto. O livro é só o mote, o pretexto para que haja um mergulho no mundo pessoal de cada um.

\section{MATERIAL E MÉTODO}


O material utilizado para a realização do trabalho foram obras selecionadas de teoria e crítica Literária e contos de Machado de Assis e Guimarães Rosa bem como, artigos de periódicos especializados, voltados para a investigação do texto literário. À leitura do material teórico e literário, seguiu-se o fichamento para, posteriormente, culminar na realização de um artigo.

\section{RESULTADOS E/OU DISCUSSÃO}

A realização dos trabalhos de orientação de iniciação científica propiciou o desenvolvimento de pesquisas, leituras e produções de texto que possibilitaram um aprofundamento nos estudos de abordagem do texto literário, da antropóloga Michèle Petit, bem como sobre contos de Machado de Assis e Guimarães Rosa, abordando seus diálogos e intertextos e possibilitando a construção de novos conhecimentos. Debruçamo-nos sobre a obra de Machado e Rosa para melhor compreender suas produções literárias, suas referências culturais e inspirações, nos desafiando a adentrar pelas áreas da filosofia, religião, história, psicologia, antropologia, já que estávamos atentas à questão dos intertextos. Refletimos que a riqueza da produção de Machado, por exemplo, demanda uma abordagem de leitura que faça com que os estudantes se aproximem da obra de modo que seja significativo para eles.

Desta forma, observamos como os mediadores de leitura, ouvidos por Petit, relatam momentos em que a leitura de contos, fábulas, poemas, mitos e lendas promovem uma verdadeira reconstrução da identidade e resgate das histórias de vidas de pessoas devastadas pelos conflitos armados, catástrofes naturais, miséria, violência, doenças, abandono e morte, ao longo da pesquisa da autora. Ou seja, observamos que é possível construir uma abordagem de leitura em que os chamados clássicos da literatura brasileira possam estar presentes numa experiência significativa de leitura para estudantes cujo cotidiano está repleto de desafios.

As experiências apresentadas neste livro nos conduzem a reflexões profundas e conclusões bastante simples: mergulhar na experiência do outro que o livro nos traz, nos possibilita a mergulhar em nós mesmos, encontrar nossos medos, fantasmas, elaborando novas compreensões.

A discussão dos resultados se dirige ao fato de que a literatura pode ser bem mais que matéria para aquisição de nota ou cumprimento de currículo escolar, mas um momento em que a vida, o que somos e acreditamos pode ser discutido, refletido, em que a historia trazida ali, ficção ou não, nos conduza a compreender um pouco mais nossas próprias histórias de vida, trazendo significado ao ato de ler o texto literário na escola.

\section{CONSIDERAÇÕES FINAIS}

O trabalho realizado promoveu o aprofundamento das reflexões sobre a obra dos escritores estudados, tanto no âmbito dos intertextos, início de nossa pesquisa, como no campo da abordagem de leitura. Reconhecemos que novas facetas se mostram na obra dos escritores, portanto, a pesquisa não se esgota, ao contrário, o universo se amplia na direção de novas discussões, acreditando ser a literatura um instrumento para o autoconhecimento, além de refletir o papel de cada um no mundo. Portanto, é preciso usar a riqueza de conteúdo da obra literária para estabelecer bases novas para os focos de ensino da Literatura. Machado de Assis, especialmente, nos propõe a avançar o olhar, ampliando os horizontes além da literatura e da ficção. Para concluir, podemos afirmar que apesar de poder ser considerada como um testemunho histórico, a literatura nos permite conhecer contextos humanos, sociais, políticos. A intertextualidade 
verificada e exemplificada nas obras pesquisadas, além de torná-las mais ricas e dinâmicas, nos possibilita dialogar com outros conhecimentos, reforçando a nossa crença de que a literatura é muito mais que ficção.

A literatura pode ser trabalhada como um suporte para a autorreflexão e, a partir desta, a exposição, discussão e busca de mudança ou tentativa de enxergar a vida e o mundo de outra maneira. A leitura do texto literário promove o deslocar-se da crise, violência ou dificuldade, e olhar para a outra margem ou possibilidade de construção de "outras margens".

\section{REFERÊNCIAS}

ASSIS, Machado de. Papéis Avulsos. São Paulo: Editora Martin Claret, 2006.

ASSIS, Machado de. Várias histórias. São Paulo: Escala Educacional, 2008.

CHALHOUB, Sidney. A História contada: capítulos de história social da literatura no Brasil. Rio de Janeiro: Nova Fronteira, 1998.

GLEDSON, John. Machado de Assis: imposturas e realismo: uma reinterpretação de Dom Casmurro. São Paulo: Companhia das Letras, 1991.

MENDES, Nancy Maria. Intertextualidade: noções básicas. In: Teoria da literatura na escola: atualização para professores de I e II graus. Org. Graça Paulino e Ivete Walty. Belo Horizonte: UFMG/FALE/Departamento de Semiótica e Teoria da Literatura, 1992. MOISÉS, Leyla Perrone. Texto, crítica, escritura. São Paulo: Editora Ática, 1993. SANT ${ }^{e e} A N N A$, Affonso Romano. Paródia, paráfrase e cia. São Paulo: Editora Ática, 1995.

PETIT, Michèle. A arte de ler ou como resistir à adversidade. São Paulo: Editora 34, 2009.

PETIT, Michèle. Os jovens e a leitura: uma nova perspectiva. São Paulo: Editora 34, 2008.

ZANI, Ricardo. Intertextualidade: considerações em torno do dialogismo. Em Questão, Porto Alegre, v. 9, n. 1, p. 121 - 132 jan. / jun. 2003.

CALVINO, Ítalo. Por que ler os clássicos. São Paulo: Companhia das Letras, 2007.

FREITAS, Guilherme. Entrevista com Michèle Petit, autora de A arte de ler. Jornal O Globo. 20/02/2010.

PENNAC, Daniel. Como um romance. Rio de Janeiro: Rocco, 1995. 